\title{
Impacts of Climatic Changes on Paddy Production in Malaysia: Micro Study on IADA at North West Selangor
}

\author{
Md. Mahmudul Alam* \\ PhD Student \\ Institute for Environment and Development (LESTARI) \\ National University of Malaysia (UKM) \\ 43600 UKM Bangi, Selangor Darul Ehsan, Malaysia \\ E-mail: rony000@gmail.com \\ Chamhuri Siwar \\ Emeritus Professor \\ Institute for Environment and Development (LESTARI) \\ National University of Malaysia (UKM) \\ 43600 UKM Bangi, Selangor Darul Ehsan, Malaysia \\ E-mail: csiwar@ ukm.my \\ Basri Talib \\ Associate Professor \\ Faculty of Economics and Business \\ National University of Malaysia (UKM) \\ 43600 UKM Bangi, Selangor, Malaysia \\ E-mail: basri@ukm.my \\ Mohd Ekhwan bin Toriman \\ Deputy Vice Chancellor (Research \& Innovation) \\ Universiti Sultan Zainal Abidin (UniSZA) \\ 21300 Kuala Terengganu \\ Terengganu, MALAYSIA \\ E-mail: ekhwan@unisza.edu.my \\ * Corresponding Author
}

\section{Citation Reference:}

Alam, M.M., Siwar, C., Talib, B., and Mohd Ekhwan, T. 2014. Impacts of Climatic Changes on Paddy Production in Malaysia: Micro Study on IADA at North West Selangor, Research Journal of Environmental and Earth Sciences, Vol. 6(5), pp. 251-258. [Online Link]

This is a pre-publication copy.

The published article is copyrighted by the publisher of the journal. 


\title{
Impacts of Climatic Changes on Paddy Production in Malaysia: Micro Study on IADA at North West Selangor
}

\begin{abstract}
Climate change has mixed impacts on agriculture that differ among the areas, periods, and crops. The changing factors of climate, especially rainfall and temperature, have been causing very strong negative impacts on Malaysian agriculture. Projection shows that the gap between current and potential yields will increase more in future that would lead to an unsustainable nature of agriculture in Malaysia. Based on the time series linear and log linear OLS regression model, this paper discusses the impacts of rainfall and temperature on the paddy sector by using the micro data of IADA at North West Selangor, Malaysia from 1992 to 2007. This study found that the output of micro data varies with the aggregate data, and concludes that both temperature and rainfall have significant negative impacts on paddy production. It also provides policy recommendations and action plans to adapt and to cope properly with the changing nature of climate factors.
\end{abstract}

Key words: Climate Change, Rainfall, Temperature, Technology, Paddy Production

\section{Introduction}

Agriculture is primarily and heavily dependent on climate. The climatic factors - rainfall, sunshine hours, temperature, relative humidity, and length of the drought period - result in cycle-to-cycle variability of crops production. The uncontrollable natures of climate factors are changing over time affecting agricultural, economic, social, and environmental sustainability of a country.

The global effect of climate change on agricultural production is small to moderate, where regional impacts are significant for many areas, because regional variations in gains and losses result in a slight overall change in world cereal grain productivity. The impacts of climate change on agricultural production vary from economic conditions of country to country, region to region and time to time. 
The effect on agricultural crops in Malaysia is heavily influenced by the variations of climate factors. This study focuses on the micro level data with the aggregate data of Malaysia to compare the impacts of climate change on paddy production. This paper also provides policy recommendations and action plans to adapt and to cope properly with climate change.

\section{Literature Review}

The National Academy of Science (2001) found trends of increasing average temperature and more volatile rainfall patterns. A recent IPCC report in 2007 further showed scientific evidence that the world's climate systems are changing faster than predicted, that would lead to raising the likelihood of more rapid and damaging changes. It also mentioned that human actions cause $90-95 \%$ likelihood of modern climate changes.

According to the Third Assessment Report of IPCC (2001), if the levels of emissions are not reduced, the global average temperature will increase by $1.4^{\circ} \mathrm{C}$ to $5.8^{\circ} \mathrm{C}$ between 1990 and 2100. Another projection said an increase in the average global temperature of $2.4^{\circ} \mathrm{C}$ between 1990 and 2100 , with a $95 \%$ chance that the change will be between $1.0^{\circ} \mathrm{C}$ and $4.9^{\circ} \mathrm{C}$ (Webster et al., 2002). Other studies have estimated that the average global temperature is likely to rise by between $0.3^{\circ} \mathrm{C}$ and $1.3^{\circ} \mathrm{C}$ during the next 30 years (Zwiers 2002).

About $60 \%$ of the world and $90 \%$ for sub-Saharan African staple food production are under direct rainfed agriculture (Savenije 2001; Hatibu 2002). However, in sub-Saharan Africa, most of the crop failures are due to deficit in soil moisture (Hatibu and Mahoo 2000) caused by dry spells. Around $80 \%$ of the world's agricultural land is rainfed which contributes to at least two-thirds of global food production. In spite of the higher risks in rainfed agriculture, especially in drought-prone areas, there is no alternative but most of the food comes from rainfed agriculture (Falkenmark et al. 2001). On the other side, rainfall plays a destructive role for agriculture. Heavy rainfall at the end of the crop cycle causes damages to crops and financial losses to the farmers. Excessive rainfall also causes flood that causes huge damages to crops and land fertility.

The IPCC mentioned Africa as one of the most vulnerable continents to climate change (Boko et al. 2007). Very few parts of Africa will benefit from a rising temperature, 
unlike some parts of the northern hemisphere (Canada, Japan, Russia). The UN Framework Convention on Climate Change (UNFCCC) identifies a list of 49 Least Developed Countries (LDCs), which are at high risk from climate change, where 33 are located in Africa. A study analyzed that due to climate change, Southern Africa will lose more than $30 \%$ of its main crop, maize, by 2030, and Asia, especially South Asia and South East Asia will lose top 10\% of many regional staples, such as rice, millet, and maize (Lobell et al. 2008).

Some studies addressed climate change impacts on rice yields, which vary greatly, in South and Southeast Asia based on climate scenario, geographic scope and study types (Matthews et al. 1994a, 1994b). In the case of China where large changes have been predicted, but due to diversification of cropping systems, to a certain extent, warming would be beneficial with yield increasing. In the case of Japan, the positive effect of $\mathrm{CO} 2$ on rice yields is generally more to offset the negative effects of climatic change (Grasty 1999).

Under current climate change scenario, temperatures above $25^{\circ} \mathrm{C}$ may decline grain mass of $4.4 \%$ per $1^{\circ} \mathrm{C}$ rise (Tashiro and Wardlaw 1989), and grain yield may decline as much as $9.6 \%-10.0 \%$ per $1{ }^{\circ} \mathrm{C}$ rise (Baker and Allen 1993), where average temperature in rice growing areas in Malaysia is about $26^{\circ} \mathrm{C}$. Singh et al. (1996) mentioned that the actual farm yields of rice in Malaysia vary from 3-5 tons per hectare, where potential yield is 7.2 tons. It also mentioned a decline of rice yield between $4.6 \%-6.1 \%$ per $1{ }^{\circ} \mathrm{C}$ temperature increase under the present $\mathrm{CO}_{2}$ level, but a doubling of $\mathrm{CO}_{2}$ concentration (from present level 340ppm to $680 \mathrm{ppm}$ ) may offset the detrimental effect of $4^{\circ} \mathrm{C}$ temperature increase on rice production in Malaysia.

Various previous studies have also contributed to predict and measure the changes in agriculture due to climate change in Malaysia based on macro studies (Ali and Ali 2009; Alam et al. 2011a, b; Tilman et al. 2002; Socolow 1999; Alexandratoss 1999; Reilly 1999; Schimmelpfenning et al. 1996; Singh et al. 1996; Penning de Vries 1993). Here, this study is based on the micro data to find out the more rigorous impacts of climate change on paddy production in Malaysia.

\section{Research Methodology}


This study uses the data set from Integrated Agricultural Development Area (IADA), West Selangor, Malaysia. IADA in West Selangor consists of eight areas - Sawah Sempadan, Sg. Burong, Sekinchan, Sg. Leman, Pasir Panjang, Sg. Nipah, Panchang Bedena, Bagan Terap where it measures the value of the variable for each area separately. This study uses the average value of all eight areas. Among the eight areas paddy production season differs month to month so that while calculating temperature and rainfall for the $1^{\text {st }}$ season, this study uses the average of first half of the year data (Jan- Jun), and for the $2^{\text {nd }}$ season the average of second half of the year data (Jul- Dec). For the rainfall data, it uses the average of "total monthly rainfall $\mathrm{mm}$ " data, and for temperature it uses average of "average monthly temperature ${ }^{\circ} \mathrm{C} "$ data from 1992 to 2007.

To determine the relationship of the paddy production with the temperature, and paddy production with rainfall, this study conducts multiple OLS (Ordinary Least Square) regression (Eq- 1.1) and multiple log linear OLS regression (Eq- 1.2):

$$
\begin{aligned}
& Y_{t}=\alpha_{11}+\beta_{11} X_{1 t}+\beta_{12} X_{2 t}+\beta_{13} X_{1 t-1}+\beta_{14} X_{2 t-1}+\beta_{15} X_{3 t}+\varepsilon_{11} \\
& \ln Y_{t}=\alpha_{21}+\beta_{21} \ln X_{1 t}+\beta_{22} \ln X_{2 t}+\beta_{23} \ln X_{1 t-1}+\beta_{24} \ln X_{2 t-1}+\beta_{25} \ln X_{3 t}+\varepsilon_{21}
\end{aligned}
$$

Here, $\mathrm{Y}_{\mathrm{t}}=$ Average Yield of Paddy Production per Season (ton/ per ha)

$\mathrm{X}_{1 \mathrm{t}}=$ Average of Monthly Rainfall per Season (mm)

$\mathrm{X}_{2 \mathrm{t}}=$ Average of Daily Temperature Rate per Season $\left({ }^{\circ} \mathrm{C}\right)$

$\mathrm{X}_{3 \mathrm{t}}=$ Technology (Dummy Data such as $\left.\mathrm{t}=1,2,3 \ldots\right)$

$\alpha=$ Constant; $\beta=$ Coefficient; $\varepsilon=$ Residual

\section{Result Analysis}

Under the IADA, North West Selangor, total available land for paddy production is 18,934 ha. Though all the areas under IADA are geographically very close, the variation of rainfall is very high. Therefore, in a particular time, the rainfall is not the same, not even close, even for very short-distanced areas. When the value of all eight areas under IADA is calculated in one average term, it is found that the overall impacts decreased compared to the impacts of individual areas (Graph 1). 


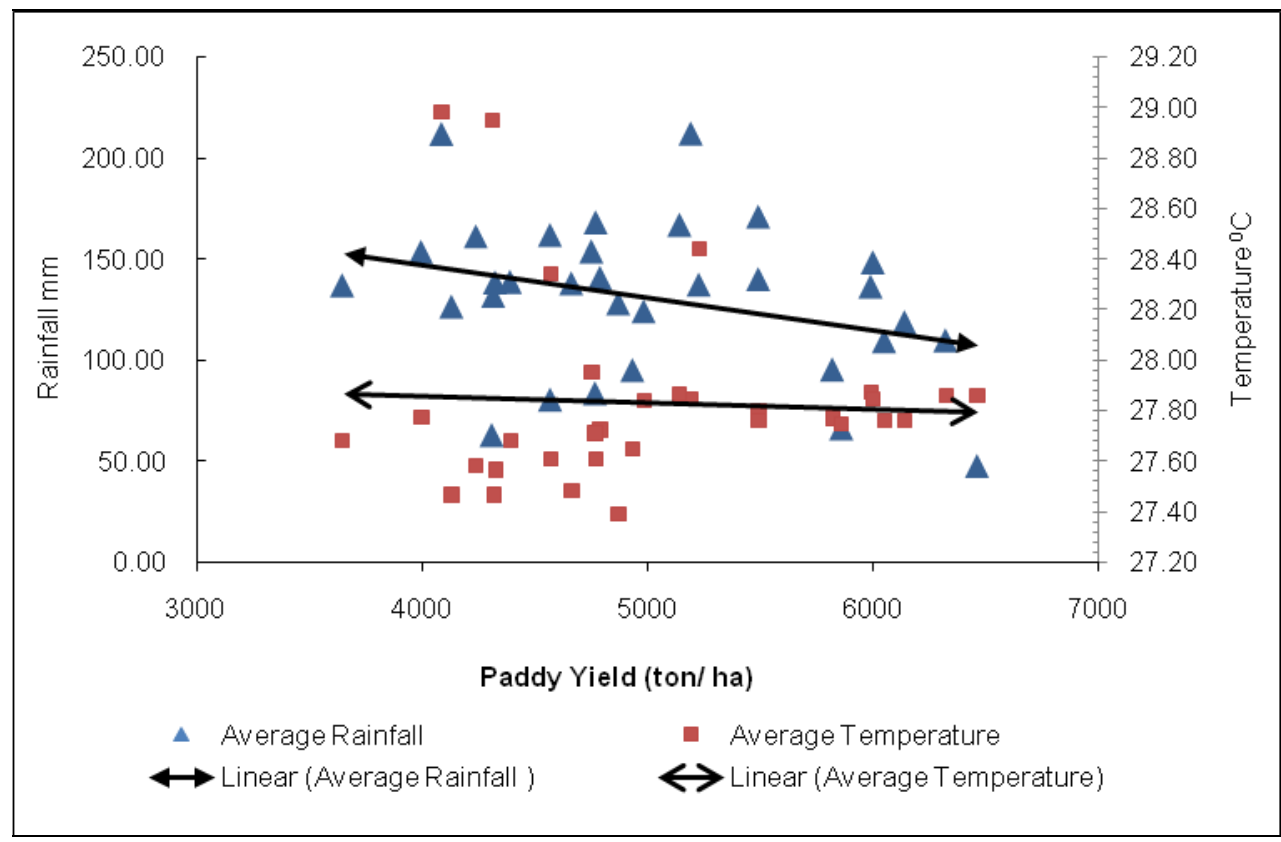

Figure 1: Rainfall, Temperature and Paddy Yield in North West Selangor, Malaysia Data Source: Integrated Agricultural Development Area (IADA), North West Selangor, Malaysia, March 2009.

The study on West Selangor shows that rainfall and temperature have significant negative relationships with paddy yields. For all the cases, the value of $\mathrm{R}^{2}$ indicates good fitness of the model. For the normal data set, the $\mathrm{R}^{2}$ is 0.84 which means the independent variables explain $84 \%$ of the dependent variable, and for the ln data set, the $\mathrm{R}^{2}$ is 0.72 which means the independent variables explain $72 \%$ of the dependent variable. For both cases, the DW value is under the inconclusive zone. As the autocorrelation decision is not conclusive, based on very low significance value of the F statistics, the validity of the models is accepted.

Although the normal data do not show any significant relationship between rainfall and paddy yield, the $1 n$ value shows significant relationship at very low significance level (3\%). The elastically value shows that a $1 \%$ increase of rainfall leads to a $.12 \%$ decrease in paddy yield. Moreover, at $1 \%$ significance level, there is significant negative relationship between paddy yield and rainfall of previous season with the ln data set. The elasticity value shows that a $1 \%$ increase in rainfall will lead to $.21 \%$ decrease in paddy yield in the following season. 
Table 1: Statistical Output for Paddy Production on Rainfall and Temperature in North-West Selangor, Malaysia

\begin{tabular}{|c|c|c|c|c|c|c|c|c|}
\hline Eq. No. & $\begin{array}{c}\text { Dependent } \\
\text { Variable }\end{array}$ & $\begin{array}{c}\text { Independent } \\
\text { Variables }\end{array}$ & Coefficient & t-stat & P-value & DW stat & Observations & $\mathbf{R}^{2}$ \\
\hline $\begin{array}{l}\text { OLS } \\
(1.1)\end{array}$ & $Y_{t}$ & $\begin{array}{c}\alpha \\
X_{1 \mathrm{t}} \\
\mathrm{X}_{2 \mathrm{t}} \\
\mathrm{X}_{1 \mathrm{t}-1} \\
\mathrm{X}_{2 \mathrm{t}-1} \\
\mathrm{X}_{3 \mathrm{t}} \\
\end{array}$ & $\begin{array}{r}20290.94 * \\
-389.97 \\
-3.32 \sim \\
-158.39 \\
-5.62^{*} \\
69.15^{*} \\
\end{array}$ & $\begin{array}{r}3.75 \\
-1.66 \\
-1.84 \\
-0.72 \\
-2.77 \\
9.41 \\
\end{array}$ & $\begin{array}{l}0.00 \\
0.11 \\
0.08 \\
0.48 \\
0.01 \\
0.00 \\
\end{array}$ & $1.72^{\varsigma}$ & 31 & 0.84 \\
\hline $\begin{array}{c}\ln \\
\text { OLS } \\
(1.2)\end{array}$ & $\ln Y_{t}$ & $\begin{array}{c}\alpha \\
\ln X_{1 t} \\
\ln X_{2 t} \\
\ln X_{1 t-1} \\
\ln X_{2 t-1} \\
\ln X_{3 t} \\
\end{array}$ & $\begin{array}{r}25.80^{*} \\
-0.12^{\wedge} \\
-3.44^{\wedge} \\
-0.21^{*} \\
-1.40 \\
0.16^{*}\end{array}$ & $\begin{array}{r}5.56 \\
-2.33 \\
-2.12 \\
-3.16 \\
-0.97 \\
6.65\end{array}$ & $\begin{array}{l}0.00 \\
0.03 \\
0.04 \\
0.00 \\
0.34 \\
0.00\end{array}$ & $1.28^{\varsigma}$ & 31 & 0.72 \\
\hline
\end{tabular}

$*, \wedge$, and $\sim$ are significant at the $1 \%, 5 \%$ and $10 \%$ significance level, respectively.

` Autocorrelation Test: At 5\% significant Level DL=1.11 and DU= 1.82 for $\mathrm{n}=32$ and $\mathrm{k}=5$. All DW stat values are under inconclusive Zone.

Table 2: Correlation Matrix among Rainfall, Temperature and Paddy Yield

\begin{tabular}{lccc}
\hline & Paddy Yield & Rainfall & Temperature \\
\hline \hline Paddy Yield & 1 & -0.319 & -0.053 \\
Rainfall & -0.319 & 1 & -0.024 \\
Temperature & -0.053 & -0.024 & 1 \\
\hline
\end{tabular}

The temperature shows significant negative relationship with paddy yield both in the normal data set and ln data set. At 4\% significant level, the elasticity value shows that if temperature increases by $1 \%$, the yield of paddy will decrease by $3.44 \%$. Moreover, at $1 \%$ significance level, it shows temperature of previous season has a significant negative relationship with paddy yield in the following season with the normal data set. $1 \%$ increase in temperature will lead to $.03 \%{ }^{1}$ decrease in paddy yield in the following season.

Technology plays a significant role in increasing paddy yield. At $1 \%$ significance level, both normal and ln data set show that technology has a significant positive relationship on paddy yield. The elasticity value shows that a $1 \%$ improvement of technology will lead to $.16 \%$ increase of the paddy yield.

\footnotetext{
${ }^{1}$ The Elasticity is calculated as $\beta_{14} * \dot{\mathrm{X}}_{2 \mathrm{t}-1} / \overline{\mathrm{Y}}_{\mathrm{t}}$
} 
Ali and Ali (2009) showed that there is a significant positive relationship for paddy production with rainfall, and paddy production with temperature in Malaysia, based on the national data from 1980 to 2008 of Malaysia. However, based on the analysis of minimum and maximum yield of the last 28 years, they showed that the yield of paddy would decrease by $43 \%$ to $61 \%$ with a $1^{\circ} \mathrm{C}$ temperature and a $1 \mathrm{~mm}$ rainfall increase. Here, it is found that the aggregate data on overall Malaysia vary from micro cases of the core paddy production areas.

\section{Discussion}

Stern (2007: iv) mentioned that most of the warming during the next 30 years will be due to emissions that have already occurred. Over the longer term, the degree and pace of warming depends mainly on current and near future emissions. There is a more than $50 \%$ chance that in the longer term the temperature rise would exceed $5^{\circ} \mathrm{C}$. Due to the climate change impacts, the amount of $5 \%$ of the global GDP, which regionally goes up to even $20 \%$, is expected to suffer annual loss in the future.

In Malaysia, the most challenging issue is the current activities that lead to rapid climate change. According to the United Nations Development Report, carbon dioxide emissions in Malaysia increased by 221\% during the period of 1990 to 2004, which is included in the list of 30 biggest greenhouse gas emitters. Curb Global Warming (2007) also mentioned that rapid growth in emissions has occurred even though Malaysia ratified the Kyoto Protocol and has taken several initiatives to use renewable energy as well as ways to cut emissions. Currently, Malaysia ranks as the 26th largest greenhouse gas emitter in the world with a population of about 27 million, and it appears likely to move up the list quickly due to the growth rate of emissions.

Due to high greenhouse gas emissions, the temperature is projected to rise by $0.3^{\circ} \mathrm{C}$ to $4.5^{\circ} \mathrm{C}$ in Malaysia. Warmer temperature will cause a rise in the sea level by about $95 \mathrm{~cm}$ over a hundred year period. The changes in rainfall may fluctuate from about $-30 \%$ to $+30 \%$. This change will reduce crop yield and be prone to drought in many areas so that cultivation of some crops such as rubber, oil palm, and cocoa will not be possible (Ramadasan et al. 2001).

Based on the ongoing activities that strongly influence the climate factors in Malaysia, the projection (table 3 ) of rainfall and temperature shows a very alarming situation 
in the future. The projection also shows that by 2050, a maximum monthly precipitation will increase up to $51 \%$ over Pahang, Kelantan, and Terengganu, while minimum precipitation will decrease between $32 \%$ to $61 \%$ for all over Peninsular Malaysia. Consequently, annual rainfall will increase up to $10 \%$ in Kelantan, Terengganu, Pahang and North West Coast, and decrease to 5\% in Selangor and Johor (NAHRIM 2006). As the current situation of rainfall and temperature is unsuitable for agriculture, any variation of these factors will cause the total agricultural system to be vulnerable in Malaysia.

Table 3: Future Rainfall and Temperature Change Projections in Peninsular Malaysia by 2050

\begin{tabular}{|l|l|l|}
\hline \multicolumn{1}{|c|}{ Area } & \multicolumn{1}{c|}{ Projected Change* in Maximum Monthly } \\
\multicolumn{1}{|c|}{ Value } \\
\hline Regions/Sub-regions/states & Temperature $\left({ }^{0} \mathrm{C}\right)$ & Rainfall (\%) \\
\hline $\begin{array}{l}\text { North East Region -Terengganu, Kelantan, Northeast- } \\
\text { coast }\end{array}$ & +1.88 & +32.8 \\
\hline North West Region-Perlis (west coast), Perak, Kedah & +1.80 & +6.2 \\
\hline Central Region-Klang, Selangor, Pahang & +1.38 & +8.0 \\
\hline Southern Region-Johor, Southern Peninsula & +1.74 & +2.9 \\
$*$ Difference = Average 2025-2034 \& 2041-2050 minus Average 1984-1993 & & \\
\hline
\end{tabular}

Source: NAHRIM, 2006.

\section{Recommendations and Policy Options}

As climate change is a continuous and long term process, its effects and solution are similarly time consuming and a painstaking process. It is widely accepted that strict mitigation efforts will not be sufficient to avoid significant impacts of climate change (IPCC 2007). It is therefore important to balance between measures against the causes of climate change and measures to cope with its adverse effects (Stern 2007; Pielke et al. 2007).

In the current world, as climate factors are exogenous and uncontrollable factors, only adaptation with the changing nature of climate is the way to cope with the problem (Alam et al., 2010, 2012c). Agricultural adaptation options can be grouped as technological developments, government programs, farm production practices, and farm financial management (Smit and Skinner 2002). 
Technological adaptation is most important to deal with the problem in the long run. Rockstrom et al. (2007) said that there is a large yield gap in rainfed agriculture, especially in Asia and Africa, where most of the world's poor live. Here, agricultural policies and investments need to be more strategic. To remedy the problem, improvement of technology needs to reach such a level to control the climate factors. Based on the high uncertainty of such technological advancement in the short period, adaptation related technology is more important for short term solution, such as, developing a resource management based technique: protect crops from excessive rainfall, solve water login problems etc., crop development: varieties of crops, rainfall tolerant plants etc., crop cycle change: shifting the timing of crop cycles, reducing the timing of crop cycles etc.

Government needs to carefully define its subsidy supports and incentive programs to influence farm-level production practices and financial management. Further, it needs to define and ensure the compensation and insurance facility for the affected groups - individual farmer or farm. In the planning processes, it needs to account that stakeholders may not be sufficiently informed about their needs and possible strategies (Eisenack and Kropp 2006; Eisenack, Tekken and Kropp, 2007); farm level future uncertainties and developments may hinder the process and implementation of adaptation policies (Behringer et al. 2000; Brown et al. 2007), and it will deal with different conflicting interest groups.

The production practices of farms and individual farmers need to be updated with the changes of climate factors. They should understand the crop rotation, crop portfolio, and crop substitutions. They should also take all precautions and be aware about the uncertainty of low rainfall and heavy rainfall. They must be careful to arrange proper water management, both in terms of irrigation facilities and quick water logout facilities. They also need to understand proper timing and move quickly with the warning or sign of rainfall. Moreover, the financial management of farms and farmers also need to be secured for a minimum of two seasons so that if crops are damaged in one season, they will have the seeds for the next season, will be able to bear the cost of another crop production, and able to survive financially up to the collection period of new crops. For that reason, they should take initiatives for crop sharing, forward rating, hedging, and insurance etc. (Alam et al. 2012a, b).

Mitigation or adaptation of climate change is an issue that concerns all sectors and levels of political, administrative, economic and everyday life. To better cope with these 
problems, cooperation is necessary across countries, sectors, and administrative levels. Relevant actors are needed to be aware of the benefits of cooperation to gain long-term benefits instead of focusing only on short-term and individual interest.

\section{Conclusion}

This study found that the impacts of climate change on paddy production vary by using micro data of the core paddy production areas and aggregate data on overall Malaysia. The data on core paddy production area should provide a more accurate scenario rather than using macro data. Therefore, when making policies related to paddy, policy makers need to be more concerned about the data of the production area rather than the aggregate data. This study found that both temperature and rainfall have significant negative impacts on paddy production. A $1 \%$ increase in temperature will lead to $3.44 \%$ decrease in current paddy yield, and $.03 \%$ decrease in paddy yield in the following season. A $1 \%$ increase in temperature will lead to .12\% decrease in current paddy yield, and $.21 \%$ decrease of paddy yield in the following season.

Based on increasing carbon dioxide emissions in Malaysia, different projections show a more volatile pattern of rainfall and increasing temperature in the future. Different studies have already mentioned that actual farm yields of rice in Malaysia is currently far below the potential yield. This gap will increase further in the future, based on the projected change of climate factors, which ultimately shows the unsustainable nature of Malaysian agriculture.

Adaptation is very essential for long run agricultural sustainability and relevant human livelihood sustainability in Malaysia. Adaptation approach should be followed in farms or at an individual farmer level, and policy level. Technological advancement will play the most crucial role to solve the problem in the long run. Technology shows a significant positive relationship with paddy production. $1 \%$ improvement of technology will lead to $.16 \%$ increase of the paddy yield. Thus, technology needs to develop to solve the problem such as controlling the pattern of rainfall, sunshine, or to improve shielding resources such as, protecting crops from excessive rainfall, solving water login problems, or to develop defensive approaches such as varieties of crops development, rainfall and temperature tolerant plants, or to find alternative approaches such as changing crop cycles and reducing the timing of crop cycles. Government also needs to make proper subsidy policies and ensure financial sustainability for the farmers and farms. Overall, co-operation among different 
groups, stakeholders, and agencies is very important to cope better with the changing nature of climate factors.

\section{Acknowledgement}

We are thankful to Ministry of Science, Technology and Environment of the Government of Malaysia for generously funding the research, under the Research University Grant (UKMGUP-PI-08-34-081) and UKM project on " Greening the Economy: Impacts on Sustainable Livelihood and Socioeconomic Wellbeing of Lower Income Households in Malaysia" (FRGS/1/2012/SS07/UKM/01/3).

\section{References}

Alam M.M., Siwar C., and Al-Amin A.Q. 2010. Climate Change Adaptation Policy Guidelines for Agricultural Sector in Malaysia. Asian Journal of Environmental and Disaster Management 2(4):463- 469. DOI 10.3850/S1793924011000873 Cited 05 Nov 2012

Alam M.M., Toriman M.E., Siwar C., and Talib B. 2011a. Rainfall variation and changing pattern of agricultural cycle. American Journal of Environmental Science 7(1):82-89. DOI 10.3844/ajessp.2011.82.89 Cited 05 Nov 2012

Alam, M.M., Siwar C., Murad M.W., and Toriman M.E. 2011b. Impacts of Climate Change on Agriculture and Food Security Issues in Malaysia: An Empirical Study on Farm Level Assessment. World Applied Sciences Journal 14(3): 431-442. http://idosi.org/wasj/wasj14(3)11/12.pdf Cited 05 Nov 2012

Alam, M.M., Siwar, C., Mohd Ekhwan, T., Molla, R.I., and Talib, B. 2012a. Climate Change Induced Adaptation by Paddy Farmers in Malaysia, Mitigation and Adaptation Strategies for Global Change 17(2): 173-186. http://www.springerlink.com/content/w443477600871315/ Cited 05 Nov 2012

Alam, M.M., Siwar, C., Molla, R.I., Talib, B., and Mohd Ekhwan, T. 2012b. Paddy Farmers' Adaptation Practices to Climatic Vulnerabilities in Malaysia, Mitigation and Adaptation Strategies for Global Change 17(4): 415-423. http://www.springerlink.com/content/31427ppr79181715/ Cited 05 Nov 2012

Alam, M.M., Siwar, C., Talib, B., Mokhtar, M., and Mohd Ekhwan, T. 2012c. Climate Change Adaptation Policy in Malaysia: Issues for Agricultural Sector, African 
Journal of Agricultural Research 7(9): 1368-1373.

http://www.academicjournals.org/ajar/PDF/pdf2012/5\%20Mar/Alam\%20et\%20al.pdf Cited 05 Nov 2012

Alexandratoss, N. 1999. World food and agriculture outlook for the medium and longer term. Proceedings of the National Academy of Sciences 96: 5908-5914.

Ali, R., and Ali, A. K. 2009. Estimating the Prospective Impacts of Global Warming on Malaysian Agriculture, Proceeding of 2nd National Conference on Agro-Environment 2009, MARDI, 24-26 Mar. Malaysia.

Baker, J. T. and Allen, Jr. L. H. 1993. Contrasting crop species responses to $\mathrm{CO}_{2}$ and temperature: rice, soybean and citrus. Vegetatio 104/105: 239-260.

Behringer, J., Buerki, R., and Fuhrer, J. 2000. Participatory integrated assessment of adaptation to climate change in Alpine tourism and mountain agriculture, Integrated Assessment 1: 331-338.

Boko, M., Niang, I., Nyong, A., Vogel, C., Githeko, A., Medany, M., Osman-Elasha, B., Tabo, R. and Yanda, P. 2007. 'Africa' in Climate Change 2007: Impacts, Adaptation and Vulnerability. Contribution of Working Group II to the Fourth Assessment Report of the Intergovernmental Panel on Climate Change, Parry, M. L., Canziani, O.F., Palutikof, J. P., Van der Linden, P. J. and Hanson, C. E. (Eds.), Cambridge University Press: Cambridge, UK.

Brown, K., Few, R. and Tompkins, E. L. 2007. Climate change and coastal management decisions: insights from Christchurch Bay, Coastal Management 35(2-3): 255-270.

Curb Global Warming. 2007. Malaysia Leads the World in Greenhouse Gas Emission Growth Rate. Available at <http://curbglobalwarmingblog.blogspot.com/2007/11/malaysia-leads-world-ingreenhouse-gas.html>

Eisenack, K. and Kropp, J. 2006. Regional Stakeholder Perceptions of Climate Change: Baltic Case Study Screening, ASTRA document, Potsdam.

Eisenack, K., Tekken, V. and Kropp, J. 2007. Stakeholder Perceptions of Climate Change in the Baltic Sea Region, Coastline Reports 8, 245-255.

Falkenmark, M., Fox, P., Persson, G., and Rockstrom, J. 2001. Water Harvesting for Upgrading of Rainfed Agriculture: Problems Analysis and Research Needs. Stockholm International Water Institute, Stockholm, Sweden.

Grasty, S. 1999. Agriculture and Climate Change. Thailand Development Research Institute Quarterly Review, 14(2), 12-16. 
Hatibu, N. 2002. Rainwater management: strategies for improving water availability and productivity in semi-arid and arid areas. International Water Management Institute, Sri Lanka.

Hatibu, N., and Mahoo, H. F. (Eds.) 2000. Rainwater Harvesting for Natural Resources Management. A planning guide for Tanzania. Technical Handbook No.22. RELMA, pp. 113-114.

IPCC (Intergovernmental Panel on Climate Change). 2001. Climate Change 2001: The Scientific Basis. Houghton, J. T., Ding, Y., Griggs, D. J. et al. (Eds.), Cambridge University Press, Cambridge.

IPCC (Intergovernmental Panel on Climate Change). 2007. Climate Change 2007: The Physical Science Basis. Intergovernmental Panel on Climate Change, Cambridge University Press, Cambridge.

Lobell, D. B., Burke, M. B., Tebaldi, C., Mastrandrea, M. D., Falcon, W. P. and Naylor, R. L. 2008. Prioritizing climate change adaptation needs for food security in 2030, Science 319(5863): 607-610.

Ramadasan, K., Ghani, M. Z. A., Yew, F. K., Abdullah, M. Y. and Jaffar, H. Z. 2001. Assessment of the impacts of climate change on key economic sectors in Malaysia: Agriculture. Chong, A. L. and Mathews, P. (Eds), Malaysia national response strategies to climate change. Ministry of Science, Technology and Environment, Malaysia.

Matthews, R. B. et al. 1994a. Climate Change and Rice Production in Asia, Entwicklung und Landlicherraum 1: 16-19.

Matthews, R. B. et al. 1994b. The Impact of Global Climate Change on Rice Production in Asia: a Simulation Study. Report No. ERL-COR-821. Corvallis, OR, U.S. Environmental Protection Agency, Environmental Research Laboratory.

NAHRIM. 2006. Final Report: Study of the Impact of Climate Change on the hydrologic Regime and Water Resources of Peninsular Malaysia. National Hydraulic Research Institute of Malaysia (NAHRIM) and California Hydrologic Research Laboratory (CHRL), Malaysia.

National Academy of Science. 2001. Climate change science: An analysis of some key questions. Committee on the Science of Climate Change, National Academy Press, Washington, D.C. 
Penning de Vries, F. W. T. 1993. Rice production and climate change. Penning de Vries, F. W. T., Teng, P. S. and Metselaar, K. (Eds.). System approaches for agricultural development, IRRI, Kluwer.

Pielke, R., Prins, G., Rayner, S. and Sarewitz, D. 2007. Lifting the taboo on adaptation. Nature 445(7128): 597-598.

Reilly, J. 1999. Climate Change: Can Agriculture Adapt?. Choices 14(1): 4-8.

Rockstrom, J., Hatibu, N., Oweis, T.Y., and Wani, S. 2007. Managing water in rainfed agriculture. Molden, D. (Eds.), Water for Food, Water for Life: A Comprehensive Assessment of Water Management in Agriculture, Earthscan: London

Savenije, H. H. G. 2001. The role of Green Water in Food Production in sub-Sahara Africa. Article for FAO, pp. 5. Available at <http/www.fao.org/ag/AGL/aglw/webpub/greenwat.htm>

Schimmelpfenning, D. 1996. Uncertainty in Economic Models of Climate Change Impacts. Climatic Change 33(2): 213-34.

Singh, S., Amartalingam, R., Wan Harun, W.S., and Islam, M.T. 1996. Simulated impact of climate change on rice production in Peninsular Malaysia. Proceeding of National Conference on Climate Change. UPM, pp. 41-49.

Smit, B. and Skinner, M.W. 2002. Adaptation Options in Agriculture to Climate Change: A Typology. Mitigation and Adaptation Strategies for Global Change, 7, 85-114.

Socolow, R. H. 1999. Nitrogen management and the future of food: lessons from the management of energy and carbon. Proceedings of the National Academy of Sciences 96: 6001-6008.

Stern, N. 2007. The Economics of Climate Change: The Stern Review. Cambridge University Press, Cambridge.

Tashiro, T., and Wardlaw, I. F. 1989. A comparison of the effect of high temperature on grain development in wheat and rice, Annals of Botany 64: 59-65.

Tilman, D., Cassman, K. G., Matson, P., Naylor, R. and Polasky, S. 2002. Agricultural sustainability and intensive production practices, Science 418: 671-676.

Webster, M. et al. 2002. Uncertainty Analysis of Climate Change and Policy Response. Report no. 95. Massachusetts Institute of Technology Joint Program on the Science and Policy of Global Change. December.

Zwiers, F. W. 2002. Climate Change: The 20-Year Forecast, Nature 416: 690-691. 


\section{Appendix}

Appendix A: Historical Data of North-West Selangor, Malaysia, used for Statistical Analysis

\begin{tabular}{|c|c|c|c|c|c|c|}
\hline year & $\begin{array}{l}\text { Average } \\
\text { Rainfall }\end{array}$ & $\begin{array}{c}\text { Average } \\
\text { Temperature }\end{array}$ & $\begin{array}{l}\text { Yield of } \\
\text { Paddy }\end{array}$ & $\begin{array}{c}\text { In (Average } \\
\text { Rainfall) }\end{array}$ & $\begin{array}{c}\text { In (Average } \\
\text { Temperature) }\end{array}$ & $\begin{array}{l}\text { In (Yield } \\
\text { of Paddy) }\end{array}$ \\
\hline $1992-1$ & 94.90 & 27.65 & 4934 & 4.55 & 3.32 & 8.50 \\
\hline $1992-2$ & 138.50 & 27.68 & 4391 & 4.93 & 3.32 & 8.39 \\
\hline 1993-1 & 127.81 & 27.39 & 4871 & 4.85 & 3.31 & 8.49 \\
\hline 1993-2 & 126.28 & 27.47 & 4132 & 4.84 & 3.31 & 8.33 \\
\hline 1994-1 & 137.79 & 27.48 & 4663 & 4.93 & 3.31 & 8.45 \\
\hline 1994-2 & 160.99 & 27.58 & 4240 & 5.08 & 3.32 & 8.35 \\
\hline $1995-1$ & 136.85 & 27.68 & 3647 & 4.92 & 3.32 & 8.20 \\
\hline $1995-2$ & 153.26 & 27.78 & 3997 & 5.03 & 3.32 & 8.29 \\
\hline 1996-1 & 131.57 & 27.47 & 4317 & 4.88 & 3.31 & 8.37 \\
\hline 1996-2 & 167.84 & 27.61 & 4771 & 5.12 & 3.32 & 8.47 \\
\hline 1997-1 & 80.40 & 28.34 & 4569 & 4.39 & 3.34 & 8.43 \\
\hline $1997-2$ & 137.08 & 28.44 & 5228 & 4.92 & 3.35 & 8.56 \\
\hline 1998-1 & 62.83 & 28.95 & 4310 & 4.14 & 3.37 & 8.37 \\
\hline 1998-2 & 211.59 & 28.98 & 4087 & 5.35 & 3.37 & 8.32 \\
\hline 1999-1 & 138.24 & 27.57 & 4325 & 4.93 & 3.32 & 8.37 \\
\hline 1999-2 & 161.63 & 27.61 & 4569 & 5.09 & 3.32 & 8.43 \\
\hline $2000-1$ & 140.52 & 27.73 & 4790 & 4.95 & 3.32 & 8.47 \\
\hline $2000-2$ & 211.75 & 27.85 & 5193 & 5.36 & 3.33 & 8.56 \\
\hline $2001-1$ & 123.92 & 27.84 & 4984 & 4.82 & 3.33 & 8.51 \\
\hline $2001-2$ & 153.54 & 27.95 & 4752 & 5.03 & 3.33 & 8.47 \\
\hline $2002-1$ & 83.48 & $27.71 *$ & 4768 & 4.42 & $3.32 *$ & 8.47 \\
\hline $2002-2$ & 170.77 & $27.80 *$ & 5492 & 5.14 & $3.33 *$ & 8.61 \\
\hline $2003-1$ & 139.87 & $27.76^{*}$ & 5492 & 4.94 & $3.32 *$ & 8.61 \\
\hline $2003-2$ & 166.69 & $27.87 *$ & 5143 & 5.12 & $3.33^{*}$ & 8.55 \\
\hline $2004-1$ & 95.22 & $27.77 *$ & 5820 & 4.56 & $3.32 *$ & 8.67 \\
\hline $2004-2$ & 136.20 & $27.87 *$ & 5990 & 4.91 & $3.33 *$ & 8.70 \\
\hline $2005-1$ & 66.19 & $27.75^{*}$ & 5860 & 4.19 & $3.32 *$ & 8.68 \\
\hline $2005-2$ & 148.18 & $27.85^{*}$ & 6000 & 5.00 & $3.33 *$ & 8.70 \\
\hline $2006-1$ & 118.50 & $27.76^{*}$ & 6140 & 4.77 & $3.32 *$ & 8.72 \\
\hline $2006-2$ & 109.60 & $27.86^{*}$ & 6322 & 4.70 & $3.33^{*}$ & 8.75 \\
\hline $2007-1$ & 109.20 & $27.76^{*}$ & 6050 & 4.69 & $3.32 *$ & 8.71 \\
\hline $2007-2$ & 47.46 & $27.86^{*}$ & 6462 & 3.86 & $3.33 *$ & 8.77 \\
\hline
\end{tabular}

* The data are calculated from previous 3 relevant seasons' moving average.

Source: Integrated Agricultural Development Area (IADA), North West Selangor, Malaysia, March 2009. 